is densest, so that fuel has to be imported from the United States and Wales, or transported from Nova Scotia via the St. Lawrence-navigable only in summer. This has led the Canadian Department of Mines to give special study to the nature, preparation and storage of coals from the Sydney Area, Nova Scotia, described in a recent report by R. E. Gilmore and R. A. Strong ( $J$. Canadian Mining and Metallurgy, p. 317 ; 1933). Storage in Canada is a greater problem than in Great Britain. Observations are recorded on coal piles of depth reaching $40 \mathrm{ft}$. Even at this depth, the coal was safely stored. Washing was found to reduce the tendency of the coal to heat. The ash of these coals is fusible and therefore special attention has been given to the relation between the fusibility of the ash and the behaviour of the coke from the coal, when burnt in domestic boilers.

\section{Birds and Earthquakes}

The Long Beach earthquake of March 10, 1933, began at $5.55 \mathrm{p} . \mathrm{m}$. with the most severe of a succession of shocks which continued for twenty hours. At this time, about sunset, a flock of a hundred Brewer blackbirds (Euphagus cyanocephalus) had retired to roost in some medium-sized trees. M. P. Skinner records that although no preliminary shocks were felt by human beings, these birds became uneasy before the severe shock (Condor, 35, 200; 1933). During the shock the birds began to leave the roost, and rose slowly in ascending spirals above the trees to a height of about $140 \mathrm{ft}$. They then descended slowly and settled noisily in the roost; thereafter throughout the minor shocks they showed no sign of disturbance. At their usual time near dawn, meadow-larks and mocking-birds began to sing and kept up their morning songs in spite of the tremors that were occurring almost every minute.

\section{Nature of Saturn's White Spot}

Writing from Ocean Island, Central Pacific, a correspondent, whose name we regret to be unable to decipher, suggests that the white spot recently observed on the planet Saturn might consist of water which has been raised from lower levels into a region where it would solidify into ice-floes or snowfields. He adds, "The white spot may represent the result of a widespread heating of the lower Saturnian atmosphere and consist of a continent of ice floating in air, buoyed up above its normal level by rising air beneath it."

\section{American Association for the Advancement of Science}

THE ninety-third meeting of the American Association for the Advancement of Science will be held at Boston on December 27-30 under the presidency of Dr. H. N. Russell, professor of astronomy and director of the observatory in Princeton University. The title of the address of the retiring president, Prof. J. J. Abel, formerly professor of pharmacology in Johns Hopkins University, will be "On Poisons and Disease, and some Experiments with the Toxin of the Bacillus tetani"'. On December 30, Prof.
Harlow Shapley, director of the Harvard Observatory, will be presented with the Rumford medal of the American Academy of Arts and Sciences; his address on this occasion will be entitled "The Anatomy of a Disordered Universe". The vicepresidential addresses in the several sections will be delivered by the following: A (Mathematics), Prof. H. H. Mitchell, University of Pennsylvania; B (Physics), Prof. D. L. Webster, Stanford University ; C (Chemistry), Prof. F. C. Whitmore, Pennsylvania State College; D (Astronomy), Dr. P. W. Merrill, Mount Wilson Observatory; E (Geology and Geography), Prof. W. H. Hobbs, University of Michigan; F (Zoology), Prof. A. S. Pearce, Duke University ; G (Botany), Prof. H. L. Shantz, University of Arizona; H (Anthropology), Prof. C. H. Danforth, Stamford University; I (Psychology), Prof. W. S. Hunter, Clark University; K (Social and Economic Sciences), Prof. W. F. Ogburn, University of Chicago ; L (Historical and Philological Sciences), Dr. W. G. Leland, American Council of Learned Societies; M (Engineering), Prof. D. C. Jackson, Massachusetts Institute of Technology ; N (Medical Sciences), Prof. C. R. Stockard, Cornell University; O (Agriculture), Dr. J. H. Gourley, Ohio Experiment Station; Q (Education), Prof. S. A. Courtis, University of Michigan.

\section{Announcements}

THE following officers of the Royal Society of South Africa have been elected for 1934 : President, Dr. A. W. Rogers; Treasurer, Dr. L. Crawford; General Secretary, A. J. S. Goodwin; Editor, Prof. R. S. Adamson; Librarian, Prof. E. Newbery.

"Classics of Scrence" is the title of Catalogue 29 of Messrs. E. P. Goldschmidt and Co. Ltd., London, W.1. Its 220 items contain many rare and important original editions of works outstanding in the progress of scientific discovery. Some early books on astronomy, optics and magnetism are of special interest.

Applications are invited for the following appointments, on or before the dates mentioned :-An assistant lecturer and demonstrator in geology in the University College of South Wales and Monmouthshire The Registrar, University College, Cardiff (Jan. 1). An inspector for the purposes of the Diseases of Animals Acts, 1894-1927, in the Ministry of Agriculture and Fisheries-The Secretary, Ministry of Agriculture and Fisheries, 10, Whitehall Place, London, S.W.1 (Jan. 4). A water engineer at Liverpool-The Town Clerk, Municipal Buildings, Liverpool, 2 (Jan. 9). Examiners and assistant examiners for the School Certificate Examination of the Central Welsh Board-The Clerk to the Central Welsh Board, Cardiff (Jan. 12). A plant pathologist at the Waite Agricultural Research Institute, Adelaide-The Secretary, Universities Bureau of the British Empire, 88a, Gower Street, London, W.C.1 (Jan. 15). A special lecturer in aeronautics in University College, Hull-The Principal. 